\title{
Fluid inclusion chemistry in the exploration for Mississippi Valley-type deposits: an example from East Tennessee, U.S.A.
}

\author{
Frederick M. Haynes and Stephen E. Kesler \\ Department of Geological Sciences, University of Michigan, Ann Arbor, MI 48109-1063, U.S.A.
}

(Received 27 February 1987; accepted in revised form 7 April 1987)

\begin{abstract}
Scanning electron microscopy and energy dispersive analysis of fluid inclusion decrepitates in sparry dolomite cements associated with sphalerite mineralization in the Mascot-Jefferson City Mississippi Valley-type district of East Tennessee show a markedly lower $\mathrm{Na} / \mathrm{Ca}$ ratio than those in dolomites unassociated with ore. The exploration potential of this variation in fluid inclusion chemistry has been evaluated by analyzing inclusion decrepitates from white sparry dolomite along a $150 \mathrm{~m}$ traverse in the New Market West mine area. The traverse extends from the central portion of a large domal collapsebreccia orebody with greater than $3 \% \mathrm{Zn}$, into the dolomite-veined, but unmineralized Knox Group limestones. Ratios of $\mathrm{Na} / \mathrm{Ca}$ as low as $0.8-1.2$ were common in dolomite-hosted decrepitates from the high-grade collapse ores. This anomalous decrepitate chemistry was not observed in sparry dolomites less than $12 \mathrm{~m}$ from the margins of the breccia bodies where $\mathrm{Na} / \mathrm{Ca}$ ratios ranged from 1.8 to 3.6. Dolomite cements in low grade $(<1.0 \% \mathrm{Zn})$ parts of the collapse bodies showed the greatest variation in $\mathrm{Na} / \mathrm{Ca}$ ratio, with values ranging from 0.9 to 3.5. No systematic trends were observed in $\mathrm{K} / \mathrm{Na}$ and $\mathrm{S} / \mathrm{Cl}$ ratios from the same samples.
\end{abstract}

\section{INTRODUCTION}

GeoLoGisTs attempting to define regional and local targets in Mississippi Valley-type (MVT) exploration find themselves faced with an enormously difficult task. Even after the ore-bearing units have been recognized and successfully located, potentially mineralized strata often extend over a large spatial area, are usually flat-lying, and can be completely unexposed. In many cases, explorationists working in MVT environments have been forced to rely on grid (RHodes et al. 1984) and random walk (CALlAHAN, 1977; BRAUN, 1983) drilling to evaluate potential ground. While such efforts have been successful in locating several large MVT deposits and even districts, they require that geologists logging drill core use every available tool in extracting information from the small amount of core recovered by the drilling in order to recognize barren holes that are near ore.

Fluid inclusions offer an attractive way to enlarge the exploration target in many ore deposits. The analysis of gases in fluid inclusions, currently used in oil-field evaluation (RoEDDER, 1984; BARKER and Sullivan, 1987), has recently become an integral factor in some ore deposit environments (NoRMAN, 1983; SMITH and KesLer, 1985; KeSLER et al. 1986). Aqueous fluids, like gases, can permeate the rocks surrounding an ore body, and for the same reasons that gas anomalies might be expected in and around areas of mineralization, changes in the aqueous compositions of fluids trapped during mineralization and alteration can also be expected.

With the preceding two thoughts in mind, this study was undertaken to test whether the process(es) that cause sulfide deposition during MVT genesis require and/or produce changes in fluid chemistry, whether it be through mixing (ANDERSON, 1975; Beales, 1975; TAYlor et al., 1983), or single fluid evolution (McLimans et al., 1980; SverJensKy, 1984; EUGSTER, 1985). It was hoped that an analysis of the major element chemistry of fluid inclusions trapped in carbonate and sulfide phases might permit these differences to be recognized. In an exploration sense, any variation in inclusion chemistry might occur as a halo surrounding an ore body and effectively enlarge the exploration target. This preliminary study of ores and adjacent country rock from the Mascot-Jefferson City District of East Tennessee attempts: (a) to identify whether such chemical variations in fluid inclusion chemistry exist; (b) to determine what possible lateral extent (halo effect) they have; and (c) to evaluate the potential of using fluid inclusion chemistry as an exploration tool in East Tennessee and in MVT exploration in general.

\section{GEOLOGY OF THE MASCOT-JEFFERSON CITY DISTRICT}

The Mascot-Jefferson City (MJC) district is the largest of several Appalachian-style MVT districts exploiting solution collapse and manto-hosted ores in the early Ordovician Knox Group carbonates. Selective dissolution of limestone units within the interbedded limestone-dolomite sequence and collapse of the overlying coherent dolomite beds led to the formation of large solution collapse breccias (McCorMicK et al., 1971; HoAgland, 1976). The breccias, fortuitously exposed in the Rocky Valley thrust sheet 


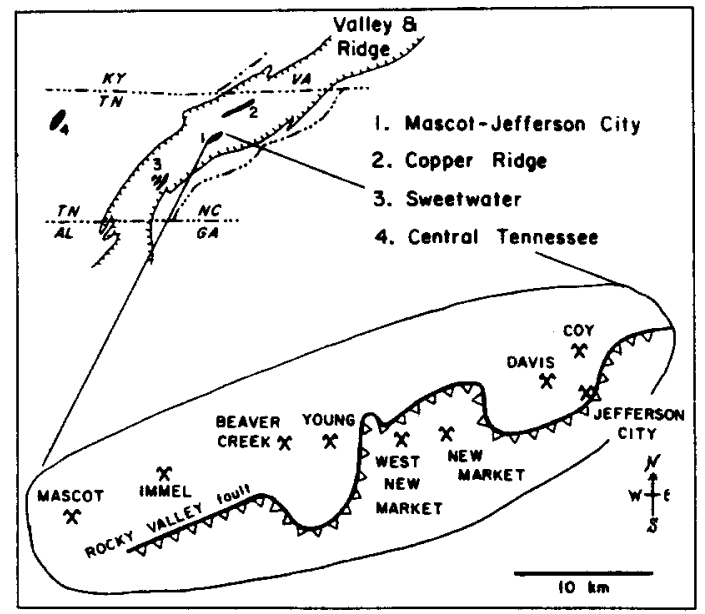

FIG. 1. Location map of the Mascot-Jefferson City zinc district within the Valley and Ridge Province of East Tennessee. The location of the New Market West breccia body sampled in this study is depicted in relation to the major mines of the district and the Rocky Valley thrust fault.

of the Appalachian Valley and Ridge Province and occurring over a strikelength of $30 \mathrm{~km}$ from the Mascot Mine in the southwest to the Coy Mine in the northeast, are cemented by gangue dolomite and sphalerite.

This study focusses on a typical collapse structure in the central part of the Mascot-Jefferson City district. The New Market West orebody lies approximately halfway between the Young and New Market Mines (Fig. 1). As a partially developed, but unmined, collapse structure it provided a unique opportunity for mapping and sampling prior to mining. The $-400 \mathrm{~W}$ haulage level of the New Market

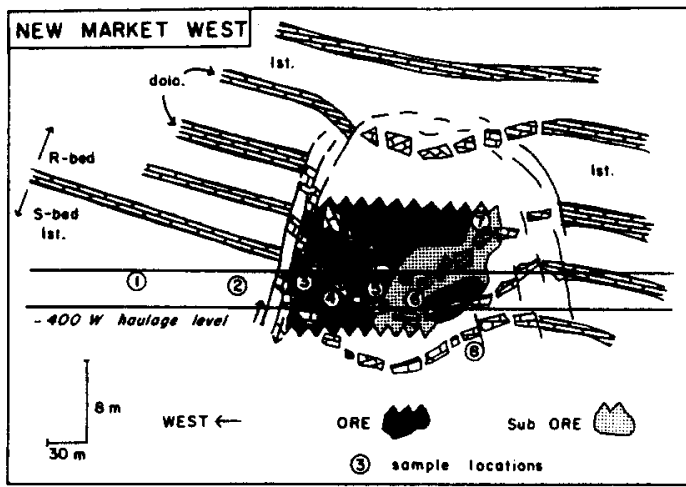

Frg. 3. Cross section of the $-400 \mathrm{~W}$ haulage level. Regional dip, local collapse within the breccia, and the location (or projection) of the samples used in this study are added.

West area (Figs 2 and 3) records a typical crosscut through a mineralized breccia and eight locations along that level were selected for sampling sparry dolomite cements (Fig. 3). Samples 1 and 2 were collected outside the collapse, 3,4 and 5 were from the ore-grade part of the collapse, 6 and 7 were in mineralized but sub-ore breccia and sample 8 was collected in a barren breccia core. Note that samples 7 and 8 were not actually collected in this drift, but are projected to it from levels $3 \mathrm{P}$ and $-400 \mathrm{~W}$, respectively.

Because the principal effort of this study was to detect spatial variations in inclusion chemistry it was desirable to minimize any effect that might be produced from sampling temporally distinct dolomites. To this end, the district-wide dolomite microstratigraphic sequence defined by EBERS and KOPP (1979)

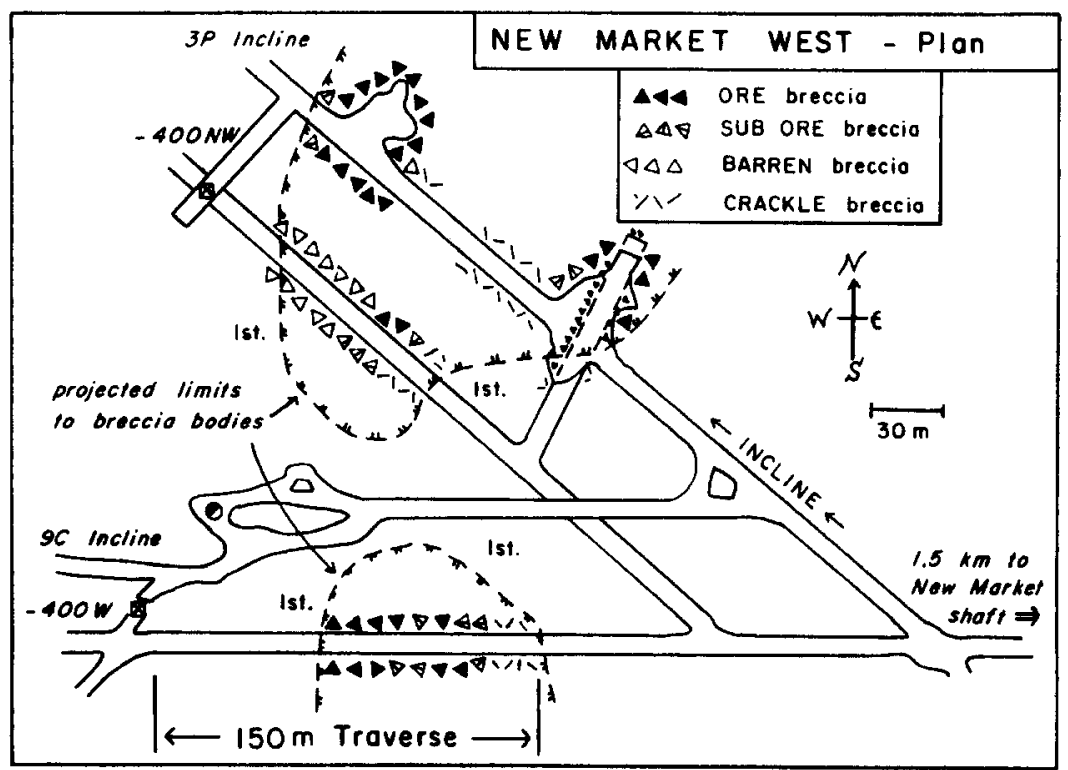

Fig. 2. Plan map of the development workings in the New Market West mine area. The limits of exposed mineralization and brecciation and the inferred extent (from underground drilling) are depicted. The 150 $\mathrm{m}$ traverse along the $-400 \mathrm{~W}$ haulage level and the location of the samples used in this study are also shown. 


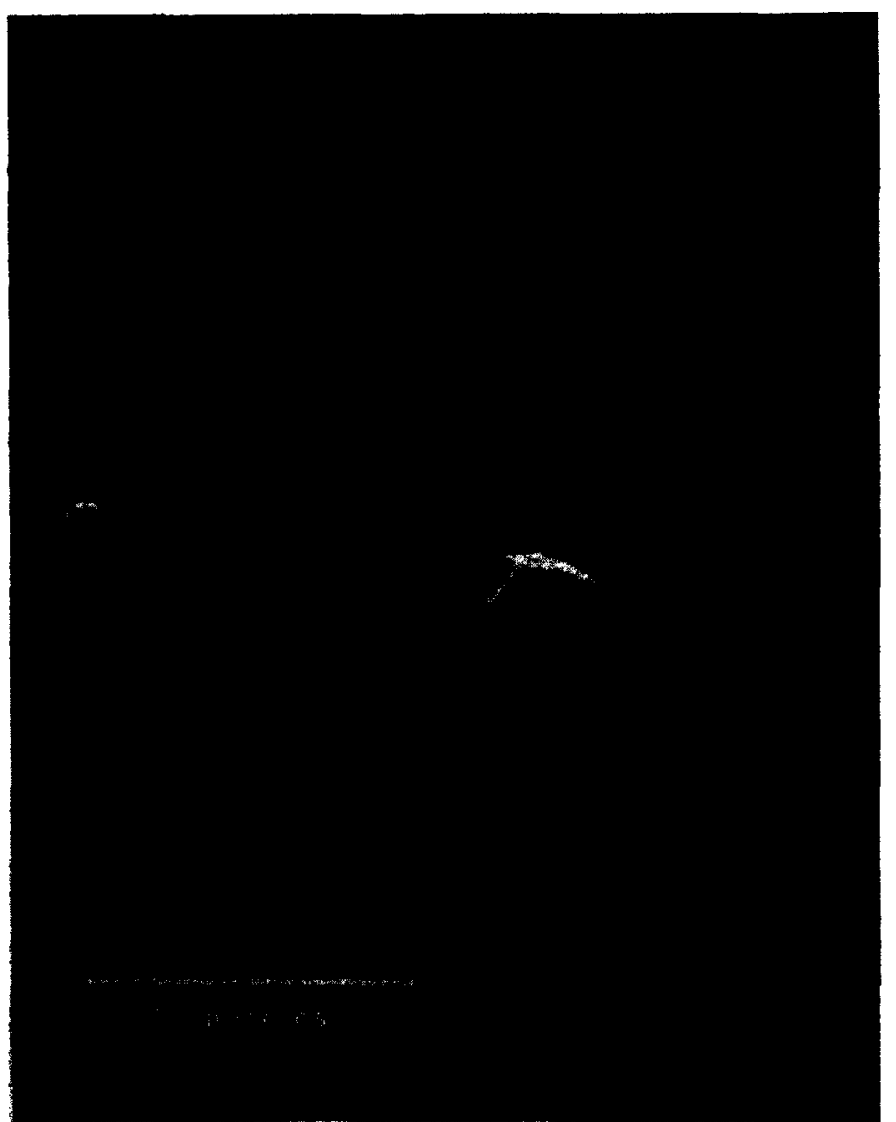

FIG. 4. Scanning electron microscopy photomicrograph of a typical decrepitate.

using cathodoluminescence was applied to isolate presumably coeval dolomite zones across the traverse. EBERS and KOPP (1979) noted a distinct pyrite-rich zone at the termination of their stage $2 d$ dolomite. Because this pyrite-rich zone could usually be identified in polished section and because the subsequent stage 3 dolomite zone which overlapped sphalerite deposition was usually wide, this zone was selected for decrepitate analyses. As discussed later, the results of this study cast doubt on the general applicability of such a technique in establishing timeequivalence between dolomite cements outside and inside the breccias.

\section{ENERGY DISPERSIVE ANALYSIS OF FLUID INCLUSION DECREPITATES}

Unfortunately no analytical method for the analysis of the major element chemistry of individual fluid inclusions is routinely applicable. Traditional fiuid inclusion thermometry (involving freezing point depression temperatures) can provide qualitative information on cation contents other than $\mathrm{Na}$ (i.e. final melt temperatures below $-20.8^{\circ} \mathrm{C}$, the eutectic in the system $\mathrm{NaCl}-\mathrm{H}_{2} \mathrm{O}$, are often interpreted to indicate the presence of $\mathrm{Ca}$ and/or $\mathrm{Mg}$ ) (Roedder, 1971, 1984). Only in rare instances are inclusions large enough to permit hydrohalite dissolution temperatures to be measured and $\mathrm{Ca} / \mathrm{Na}$ ratios to be calculated from low temperature phase relationships (CRAWFORD, 1981; KozLOWSKI, 1984; BALl et al., 1985; HAYNEs, 1985). Although these obser- vations have been made in East Tennessee in a few $\mathrm{ZnS}$ hosted inclusions (ROEDDER, 1971; TAYLOR et al., 1983), inclusions in dolomite are small (typically less than $10 \mu \mathrm{m}$ ) and optical work (particularly hydrohalite dissolution) is not possible.

EADINGTON (1974) utilized scanning electron microscopy and energy dispersive analysis to determine the composition of salts precipitated on the surface of polished quartz plates during thermal decrepitation of fluid inclusions. YPMA and FuzikAwA (1980) and CHRYssoulus and WiLkINSON (1983) employed similar methodology in studies of Australian unconformity $\mathrm{U}$ mineralization and magmatically-derived fluid inclusions in Mexican granite, respectively. We have modified the decrepitation and analysis techniques for use with sulfide and carbonate phases associated with Mississippi Valley-type mineralization (HAYNES and KESLER, 1987).

Decrepitates (Fig. 4) were produced by heating polished dolomite wafers to $350^{\circ} \mathrm{C}$, a temperature in excess of the decrepitation temperature of the inclusions. Upon rupture and release of the inclusion contents to the surface, the volatile component (principally water) escaped and the non-volatiles (principally chloride salts), were deposited on the surface as miniature "volcanoes" or mounds. Major element chemistry, in the form of unstandardized elemental counts, was determined by energy dispersive analysis (EDA). All analyses were performed using rastered areas to increase the probability of a chemically homogeneous and representative excitation volume and to avoid differential element volatility associated with spot mode analysis of low atomic number elements such as $\mathrm{Na}$. Extensive testing showed that reproducible charge balanced analyses were best obtained when using rastered areas covering as much of the decrepitate as possible, count times of $150 \mathrm{~s}$, 


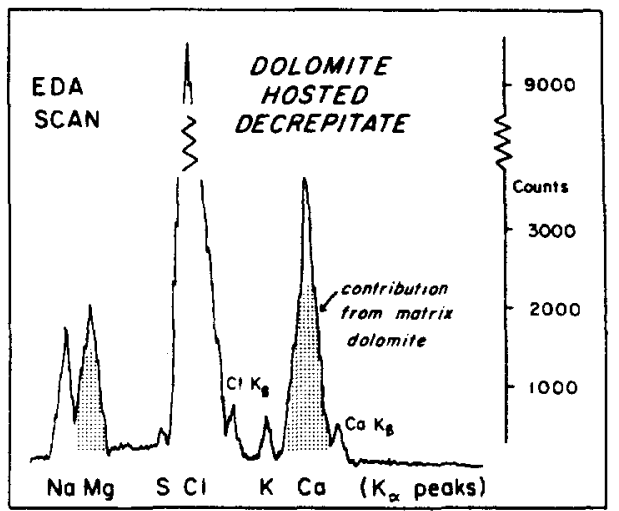

Fig. 5. A typical energy dispersive scan obtained from a rastered analysis over a dolomite-hosted decrepitate. The stippled portions of the $\mathrm{Ca}$ and $\mathrm{Mg}$ peaks represent contributions from the matrix dolomite (see text).

and operating voltages of $15 \mathrm{kV}$ (HAYNES and KESLER, 1987).

Measurable $K_{a}$ peaks for $\mathrm{Na}, \mathrm{Mg}, \mathrm{Cl}, \mathrm{K}$ and $\mathrm{Ca}$ were observed in all dolomite-hosted decrepitates (Fig. 5) and $\mathrm{S}$ was detected in about $40 \%$. Because a portion of the rastered sample area included the matrix dolomite, an appropriate amount of $\mathrm{Mg}$ and $\mathrm{Ca}$ had to be subtracted from the original analysis. Sphalerite-hosted decrepitates from throughout the district yielded consistent and low $\mathrm{Mg} / \mathrm{Cl}$ count ratios of about 0.01 (HAYNES and KESLER, 1987), and it was assumed that similar ratios existed in fluids entrapped in dolomite. Thus an amount of $\mathrm{Mg}$ equal to $1 \%$ of the $\mathrm{Cl}$ count was assigned to the decrepitate and the remainder was attributed to the dolomite host. Comparison of $\mathrm{Ca} / \mathrm{Mg}$ ratios in the matrix dolomite (which rarely varied by more than $2 \%$ ) to that of the unknown salt (Fig. 5) then permitted separation of the Ca peak into components from the host dolomite and the decrepitate. Typically, $10-40 \%$ of the $\mathrm{Ca}$ recorded from a rastered analysis of a $10-20 \mu \mathrm{m}$ diameter decrepitate was found to come from the host dolomite. Decrepitate scans where the $\mathrm{Ca}$ contribution from the host dolomite exceeded that from the decrepitate were considered unacceptable.

In this paper the results are reported in the form of unstandardized count ratios of the elements $\mathrm{Na}, \mathrm{Ca}, \mathrm{K}, \mathrm{S}$ and $\mathrm{Cl}$. Because the principal purpose of this research was to establish differences in inclusion compositions that might be applied in exploration and not to obtain quantitative solution chemistries, standardization and normalization procedures aimed at converting the count ratios to semiquantitative cation ratios (HAYNES and KESLER, 1987) were not employed. However, analyses of decrepitates produced from synthetic fluid inclusions of known composition grown in natural quartz using the technique of STERNER and BODNAR (1984), suggest that individual decrepitate analyses carry errors of $\pm 10 \%$, and that errors can be reduced to $\pm 5 \%$ by reporting modes resulting from a number of analyses (HAYnes et al., 1987). The additional error involved in correction for $\mathrm{Ca}$ from the host dolomite may lead to slightly greater errors in ratios involving $\mathrm{Ca}$.

\section{RESULTS AND INTERPRETATIONS OF DECREPITATE ANALYSES}

\section{Cations}

The ratio showing the greatest and most systematic variation along the traverse is the one relating the two

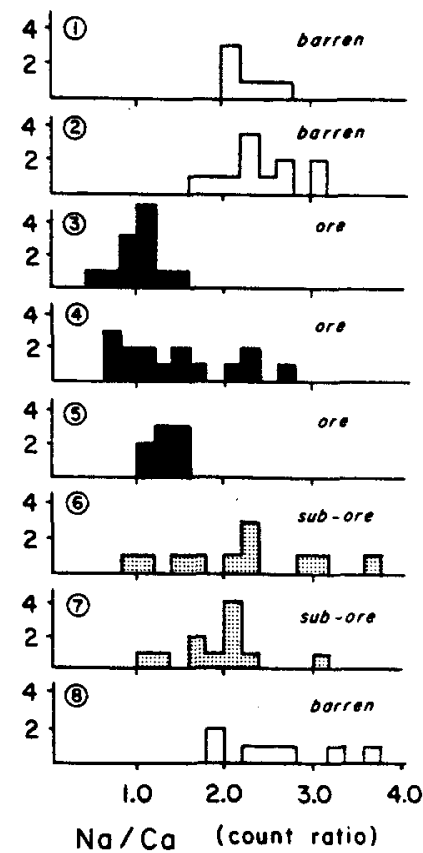

Fig. 6. $\mathrm{Na} / \mathrm{Ca}$ ratios across the traverse are plotted in stacked histograms. Count ratios are corrected for host dolomite contributions, but are unstandardized and, thus, do not record absolute ratios. Circled numbers represent sample locations (see Fig. 3).

dominant cations, $\mathrm{Na}$ and $\mathrm{Ca}$ (Fig. 6). There is a pronounced drop in the $\mathrm{Na} / \mathrm{Ca}$ ratio of the decrepitates on entering the ore zone, or perhaps more appropriately there is a marked increase in the relative Ca content of the decrepitates. While it is inviting to invoke local limestone dissolution as a source of $\mathrm{Ca}$ to explain this trend, mass balance calculations suggest that calcite dissolution, either by acid attack or upon cooling, cannot significantly alter the fluid composition of a brine already laden with $\mathrm{Na}$ and $\mathrm{Ca}$ as supporting electrolytes (HeLGeson, 1970; SvERJENSKY, 1981). We believe that this change records the presence of a distinct Ca-rich brine within the mineralized breccias. HAYNES (1986) and HAYNES $e t$ al. (in prep.) document high $\mathrm{CO}_{2}$ content, in addition to $\mathrm{Ca}$, and calculate a solution $\mathrm{pH}$ as low as 3.8 for this brine in equilibrium with dolomite. Under these moderately acidic conditions the brines would be adequate $\mathrm{Zn}$ transporters. An increase in solution $\mathrm{pH}$ or a decrease in temperature could trigger sulfide deposition. Sphalerite-hosted decrepitates also carry the low $\mathrm{Na} / \mathrm{Ca}$ values characteristic of the ore-stage dolomite (HAYNES and KESLER, 1987).

Unfortunately this anomaly in inclusion chemistry, whatever its cause(s) and implications, does not extend outside the breccia body. Sample 2, located just $12 \mathrm{~m}$ outside the contact of ore with unaltered limestone (the "limestone edge") shows no sign of the low $\mathrm{Na} / \mathrm{Ca}$ fluids. It is, however, noteworthy that the two samples of sub-ore mineralization show the greatest range in $\mathrm{Na} / \mathrm{Ca}$ ratio. They may contain 


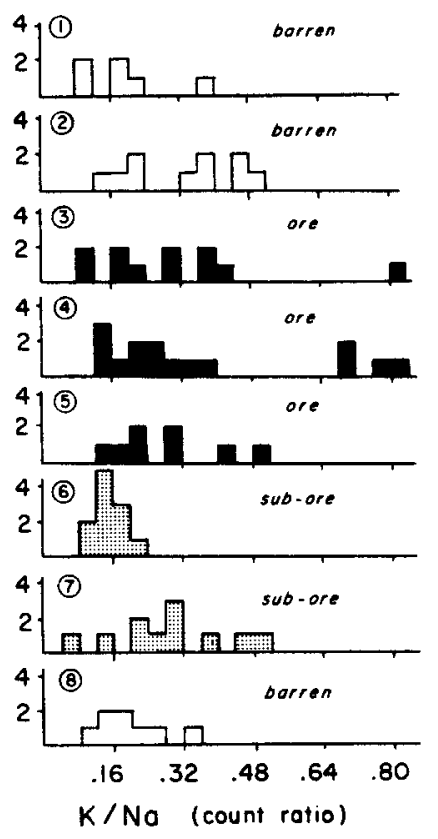

FIG. 7. $\mathrm{K} / \mathrm{Na}$ count ratios across the traverse are plotted in stacked histograms. See Fig. 6 caption for details.

inclusions of both compositions, and thus may be signalling the presence of higher grade ore nearby, but when the sub-ore and barren samples are combined the two groups are not statistically distinguishable at a $95 \%$ confidence interval. However, the decrepitates from the 3 ore-grade samples are distinguishable from either of the other two groups with $99 \%$ confidence.

The only other cation detected, aside from $\mathrm{Mg}$, was $K$. To compare $K$ content across the traverse, $\mathrm{K} / \mathrm{Na}$ count ratios were determined (Fig. 7). Despite a rather extensive range ( $\mathrm{K} / \mathrm{Na}$ count ratios varied from 0.05 to 0.48 ), the ratio did not yield an anomaly across the breccia margin that might be useful in exploration.

\section{Anions}

At the onset of the study it was anticipated that anion chemistry, principally variations in S, might define halos around mineralization. Because $S$ is directly involved in $\mathrm{ZnS}$ deposition it was hoped that $S$ might show either a depletion in the ore zone, indicating $\mathrm{S}$ removal by sphalerite deposition, or an enrichment, outlining an area where $S$ had been available for mineral deposition. The results (Fig. 8), normalized to $\mathrm{Cl}$, suggest that low and variable amounts of $\mathrm{S}$ are present in some decrepitates, but the $S$ contents do not reveal any systematic trends.

The amount of $\mathbf{S}$ in these samples, even in sample 3 , is less than that detected in any samples of orerelated dolomite analyzed from the Pine Point deposit (HAYNES and KESLER, 1987). Thus, while the

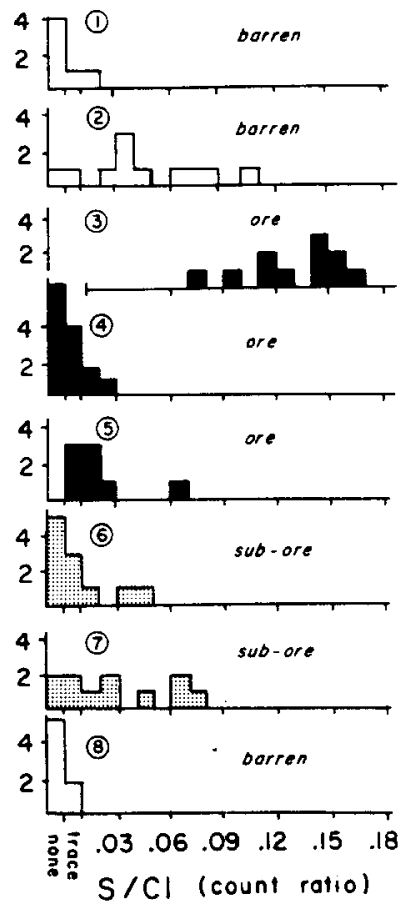

Fig. 8. S/Cl count ratios across traverse are plotted in stacked histograms. See Fig. 6 caption for details.

apparently low quantities of $\mathrm{S}$ in the East Tennessee inclusions appears to preclude its use in distinguishing mineralized from unmineralized rock in that district, it does not necessarily preclude its use elsewhere.

\section{Multiple fluids and dolomite microstratigraphy}

The documentation of distinct inclusion chemistry within petrographically similar dolomite zones from outside and inside the breccia bodies (as defined by microstratigraphy and cathodoluminescence) appears to cast doubt on the applicability of microstratigraphic correlations in defining time-equivalent cements in the two locations. If it is true that the high $\mathrm{Na} / \mathrm{Ca}$ inclusion population in the dolomites from the ore zone record a $\mathrm{Zn}$-precipitating brine which is compositionally distinct from the brine responsible for cementation in the wallrock veins less than $50 \mathrm{~m}$ away, then it seems unlikely that the two brines were present at the same time. Rather, it suggests that the microstratigraphy recorded during dolomite cementation may reflect some aspect of the interaction of any basinal brine with the host carbonates that was repeated for both brines upon entering and reacting with the Knox group carbonates.

\section{CONCLUSIONS}

Fluid inclusion decrepitate compositions in dolomite cements from the Mascot-Jefferson City zinc 
district in East Tennessee document a lower $\mathrm{Na} / \mathrm{Ca}$ ratio in samples spatially associated with ore grade sphalerite than in adjacent barren dolomite. However, the $\mathrm{Na} / \mathrm{Ca}$ perturbation observed in the ore zone samples did not extend outside the breccia zone. Two sub-ore samples adjacent to ore-grade breccia showed the greatest variation in $\mathrm{Na} / \mathrm{Ca}$ ratio suggesting that inclusion chemistry may be helpful in evaluating ground adjacent to weakly mineralized drill intercepts. It is possible that as the technology of analyzing the electrolyte compositions of inclusions catchs up with techniques of gas analysis there may be instances (fluid boiling, rock alteration phenomena) where inclusion chemistry may become a useful tool to the exploration geologist.

Acknowledgements-We are indebted to ASARCO Inc. for their financial and logistical support, and particularly to F. Graybeal, D. Harper, and J. E. McCormick, B. Hitchon and $E$. Roedder are thanked for their reviews of an earlier version of this manuscript. The decrepitate analyses were performed in the Robert B. Mitchell Electron Microbeam Analysis Laboratory at the University of Michigan; C. Henderson is acknowledged for his assistance in implementing the technique of analysis. Support for this project was also obtained from the University of Michigan Scott Turner fund and from National Science Foundation grant EAR8305909 .

Editorial handling: Brian Hitchon.

\section{REFERENCES}

ANDERson G. M. (1975) Precipitation of Mississippi Valleytype ores. Econ. Geol. 70, 937-942.

Ball T. K., Fortey N. J. and Shepherd T. J. (1985) Mineralization at the Carrock Fell Tungsten Mine, N. England: paragenetic, fluid inclusion, and geochemical study. Min. Dep. 20, 57-65.

Barker C. and Sullivan G. E. (1987) Analysis of gases in fluid inclusions in calcite cements from the deep Smackover Formation, Mississippi (Abstract). American Current Research on Fluid Inclusions (ACROFI), 5-7 Jan. 1987, Socorro, NM. Program and Abstracts.

Beales F. W. (1975) Precipitation mechanisms for Mississippi Valley-type ores. Econ. Geol. 70, 943-948.

BraUn E. R. (1983) Ore controls-Middle Tennessee zinc district. In Proc. of the Int. Conf. on Mississippi Valleytype Lead-Zinc Deposits (eds KisvarsanYI G., Grant S. K., Pratt W. P. and Koenig J. W.) Rolla, MO, 1982, pp. 349-359.

Callahan W. H. (1977) The history of the discovery of the zinc deposit at Elmwood, Tennessee-concept and consequence. Econ. Geol. 72, 1382-1392.

Chryssoulis S. and Wilkinson N. (1983) High silver content of inclusions in quartz from Guadalcazar granite, San Luis Potosi, Mexico: a contribution to ore-genesis theory. Econ. Geol. 78, 302-318.

Crawford M. L. (1981) Phase equilibria in aqueous fluid inclusions. In Mineralogical Association of Canada Short Course in Fluid Inclusions: Applications to Petrology (eds Hollister L. S. and Crawford M. L.) Vol. 6, pp. 75-100.

Eadington P. J. (1974) Microprobe analysis of the nonvolatile constituents of fluid inclusions. Neues Jahr. Min. Mh. 11, 518-525.

Ebers M. L. and KopP O. C. (1979) Cathodoluminescent microstratigraphy in gangue dolomite, the Mascot-Jefferson City District, Tennessee. Econ. Geol. 74, 908-918.

EUGSTER H. P. (1985) Oil shales, evaporites, and ore deposits. Geochim. cosmochim. Acta 49, 619-636.

HAYNES F. M. (1985) Determination of fluid inclusion composition by sequential freezing. Econ. Geol. 80, 1436-1439.

HAYNES F. M. (1986) Geologic and geochemical controls for sphalerite mineralization, Mascot-Jefferson City district, East Tennessee, Ph.D. dissertation (unpublished). University of Michigan.

Haynes F. M., Beane R. E. and Kesler S. E. An evaluation of single-solution transport of metal and sulfur, MascotJefferson City zinc district, East Tennessee: evidence from fluid inclusions (submitted to Am. J. Sci.).

HAYNes F. M. and KesLER S. E. (1987) Chemical solution evolution of brines during Mississippi Valley-type mineralization: evidence from East Tennessee and Pine Point. Econ. Geol. 82, 53-71.

Haynes F. M., Sterner S. M. and Bodnar R. J. (1987). Synthetic inclusions in natural quartz IV. Chemical analysis of fluid inclusion decrepitates by SEM/EDA: an evaluation of method (in press, Geochim. cosmochim. Acta).

Helgeson H. C. (1970) A chemical and thermodynamic model of ore deposition in hydrothermal solutions. Mineral Soc. Am. Spec. Pap. 3, pp. 155-186.

Hoagland A. D. (1976) Appalachian zinc-lead deposits. In Handbook of Stratabound and Stratiform Ore Deposits (ed. Wolf, K. H.) Vol. 6, pp. 495-534. Elsevier, Amsterdam.

Kesler S. E., Haynes P. S., Creech M. Z. and Gorman J. A. (1986) Application of fluid inclusion and rock-gas analysis in mineral exploration. J. Geochem. Explor. 25, 201-215.

KozlowskI A. (1984) Calcium-rich inclusion solutions in fluorite from the Strzegom pegmatites. Lower Silesia. Acta Geol. Pol. 34, 131-138.

McCormick J. E., Evans L. L., Palmer R. A. and Rasnick F. D. (1971) Environment of the zinc deposits of the Mascot-Jefferson City District, East Tennessee. Econ. Geol. 66, 757-762.

Mclimans R. K., Barnes H. L. and Ohmoto H. (1980) Sphalerite stratigraphy of the Upper Mississippi Valley lead-zinc district, southwest Wisconsin. Econ. Geol. 75, 351-361.

NoRman D. I. (1983) Gases in epithermal Ag-Au ore fluids (Abstract). Geol. Soc. Amer. Annual Meeting, Indianapolis, IN, Abstracts, Vol. 15.

Rhodes D., Lantos E. A., Lantos J. A., WebB K. J. and Owens D. C. (1984) Pine Point orebodies and their relationships to the stratigraphy, structure, dolomitization, and karstification of the Middle Devonian barrier complex. Econ. Geol. 79, 991-1055.

ROEDDER E. (1971) Fluid inclusion evidence on the environment of formation of mineral deposits of the southern Appalachians. Econ. Geol. 66, 777-791.

RoEdDer E. (1984) Fluid inclusions. Mineral. Soc. Amer. Rev. Min. 12.

SMITH T. J. and KesLer S. E. (1985) Relation of fluid inclusion geochemistry to wallrock alteration and lithogeochemical zonation at the Hollinger-McIntyre gold deposit, Timmins, Ontario, Canada. CIM Bulletin 78, pp. 35-46.

Sterner S. M. and Bodnar R. J. (1984) Synthetic fluid inclusions in natural quartz I. Compositional types synthesized and applications to experimental petrology. Geochim. cosmochim. Acta 48, 2659-2668.

SverJensKy D. (1981) The origin of a Mississippi Valleytype deposit in the Viburnum trend. Econ. Geol. 76, 1848-1872.

SVERENSKY D. (1984) Oil field brines as ore-forming solutions. Econ. Geol. 79, 27-37. 
Taylor M., Kesler S. E. and Cloke P. L. (1983) Fluid inclusion evidence for fluid mixing, Mascot-Jefferson City District, Tennessee. Econ. Geol. 78, 1425-1439.

YPMA P. J. M. and FuzIKaWa K. (1980) Fluid inclusion and oxygen isotope studies of the Nabarlek and Jabiluka uranium deposits, Northern Territory, Australia. In Uranium in the Pine Creek Geosyncline (eds Ferguson, J. and Goleby A. B.) Proc. of the Int. Uranium Symp., Sydney, Australia, 1979, pp. 375-395. 